e-ISSN : 2621-4105

\title{
ONLINE DISPUTE RESOLUTION (ODR) DALAM SENGKETA INVESTASI PASAR MODAL SYARIAH DI INDONESIA
}

\author{
Aista Wisnu Putra, Ro'fah Setyowati, Hendro Saptono, Rahandy Rizki Prananda \\ Fakultas Hukum, Universitas Diponegoro, Semarang \\ aistawisnuputra@gmail.com
}

\begin{abstract}
Abstrak
Tujuan dari penelitian ini adalah untuk mengetahui pengaturan Online Dispute Resolution $(O D R)$ dalam dalam sengketa investasi pasar modal syariah di Indonesia beserta keunggulan dan kekurangan ODR.Transaksi pasar modal syariah di Indonesia termasuk menjadi kegiatan ekonomi yang berkembang pada beberapa tahun terakhir. Meningkatnya transaksi pasar modal syariah menjadikan potensi sengketa antara investor dan pihak pasar modal menjadi tinggi. Oleh karena itu dibutuhkan penyelesaian sengketa yang efektif, efisien, tidak menyita banyak waktu, dan fleksibel bagi para pihak. Pengadilan agama sebagai penyelesaian sengketa jalur litigasi dianggap kurang efektif karena waktu penyelesaian kasus yang lama dan masa tunggu yang lama. Arbitrase dan alternatif penyelesaian sengketa yang lain menjadi jalan keluar mengatasi pengadilan agama yang kurang efektif dan efisien. Dengan munculnya pandemi COVID-19 di Indonesia mengakibatkan arbitrase dan alternatif penyelesaian sengketa di luar pengadilan berisiko tinggi dalam menularkan virus tersebut. Oleh karena itu $O D R$ menjadi solusi bagi penyelesaian sengketa di luar pengadilan yang perlu diteliti aturan hukum, kelebihan, dan kekurangannya dalam menangani sengketa pasar modal syariah di Indonesia.
\end{abstract}

Kata kunci: Online Dispute Resolution (ODR); Sengketa Pasar Modal; Syariah 
e-ISSN : 2621-4105

\title{
ONLINE DISPUTE RESOLUTION (ODR) FOR INVESTMENT DISPUTES IN SHARIA CAPITAL MARKET IN INDONESIA
}

\begin{abstract}
The purpose of this study is to determine the Online Dispute Resolution (ODR) arrangement in the Islamic capital market investment dispute in Indonesia and the advantages and disadvantages of ODR. Sharia capital market transactions in Indonesia have become a developing economic activity in recent years. The increase in Islamic capital market transactions increases the potential for disputes between investors and the capital market. Therefore, it requires an effective, efficient, time-consuming, and flexible dispute resolution for the parties. Religious courts as litigation dispute resolution are considered ineffective due to long time to resolve cases and long waiting periods. Arbitration and other alternative dispute resolution options provide solutions to ineffective and efficient religious courts. With the emergence of the COVID-19 pandemic in Indonesia, arbitration and alternative dispute resolution out of court have a high risk of transmitting the virus. Therefore ODR is a solution for the settlement of disputes outside the court that needs to be examined the legal rules, strengths and weaknesses in handling Islamic capital market disputes in Indonesia.
\end{abstract}

Keywords: Online Dispute Resolution (ODR); Capital Market Dispute; Sharia 


\section{A. PENDAHULUAN}

Setiap manusia selalu memiliki motif atau tujuan dalam melaksanakan kegiatan kesehariannya. Salah satu motif yang sering ada dalam tindakan manusia adalah motif ekonomi untuk melakukan tindakan ekonomi dengan tujuan memenuhi kebutuhan, memperoleh keuntungan, penghargaan, kepuasan, dan/ atau kekuasaan. Motif ekonomi pada zaman sekarang juga dapat diartikan sebagai keinginan untuk mencari uang yang menjadikan individu tertarik untuk melakukan kegiatan ekonomi. ${ }^{1}$ Transaksi ekonomi dari manusia pada zaman sekarang sangat berkembang. Transaksi ekonomi yang berkembang dalam era disrupsi dan globalisasi sekarang adalah kegiatan investasi. Investasi dapat dilakukan dengan membeli sejumlah aset untuk dijual lagi dengan harga lebih tinggi. Investasi tersebut dapat berupa membeli barang berharga untuk dijual lagi setelah naik atau investasi kepada usaha, dimana modal dari investasi akan digunakan untuk pengembangan usaha sehingga dapat menghasilkan keuntungan yang lebih tinggi. ${ }^{2}$

Salah satu kegiatan investasi yang dewasa ini sangat berkembang, adalah investasi di bidang pasar modal (Capital maket). Di Indonesia pengertian pasar modal diatur dalam Pasal 1 angka 13 undang-undang nomor 8 tahun 1995 tentang pasar modal. Pasar modal didefinisikan sebagai kegiatan yang berkaitan dengan penawaran umum (public offering) dan perdagangan efek. Kemudian pasar modal dikaitkan juga dengan perusahaan publik yang berkaitan dengan efek yang diterbitkannya. Lalu lembaga dan profesi yang berkaitan dengan efek. Semua hal tersebut adalah hal-hal yang terkait pasar modal.

Kegiatan investasi dalam bidang pasar modal di dunia dalam beberapa tahun terakhir berkembang dengan pesat. Investasi dalam pasar modal menjadikan lalu lintas modal antar negara meningkat, hal ini sangat penting bagi pembangunan ekonomi

\footnotetext{
${ }^{1}$ Herring Shava dan Willie T Chinyamurindi, "The influence of economic motivation, desire for independence and self-efficacy on willingness to become an entrepreneur," The Southern African Journal of Entrepreneurship and Small Business Management 11(1), 2019, pp 12, https://doi.org/10.4102/sajesbm.v11i1.234.

${ }^{2}$ Miriam Zuk et al., "Gentrification, Displacement, and the Role of Public Investment," Journal of Planning Literature 33(1), 2018, pp 31-44, https://doi.org/10.1177/0885412217716439.
} 
sebuah negara. ${ }^{3}$ Di Indonesia berdasarkan perkembangan investasi di bidang pasar modal juga terhitung meningkat. Berdasarkan statistik dari Otoritas Jasa Keuangan (OJK) grafik indeks harga saham gabungan (IHSG) dan nilai rata-rata perdagangan harian per bulan dari tahun 2015 sampai dengan Juli 2020 cenderung naik, dengan nilai perdagangan kurang lebih mencapai 16 triliun rupiah pada tahun 2109. Namun memang pada awal tahun 2020 turun karena adanya pandemi virus COVID-19. ${ }^{4}$ Gambaran tersebut tercermin dalam grafik 1 .

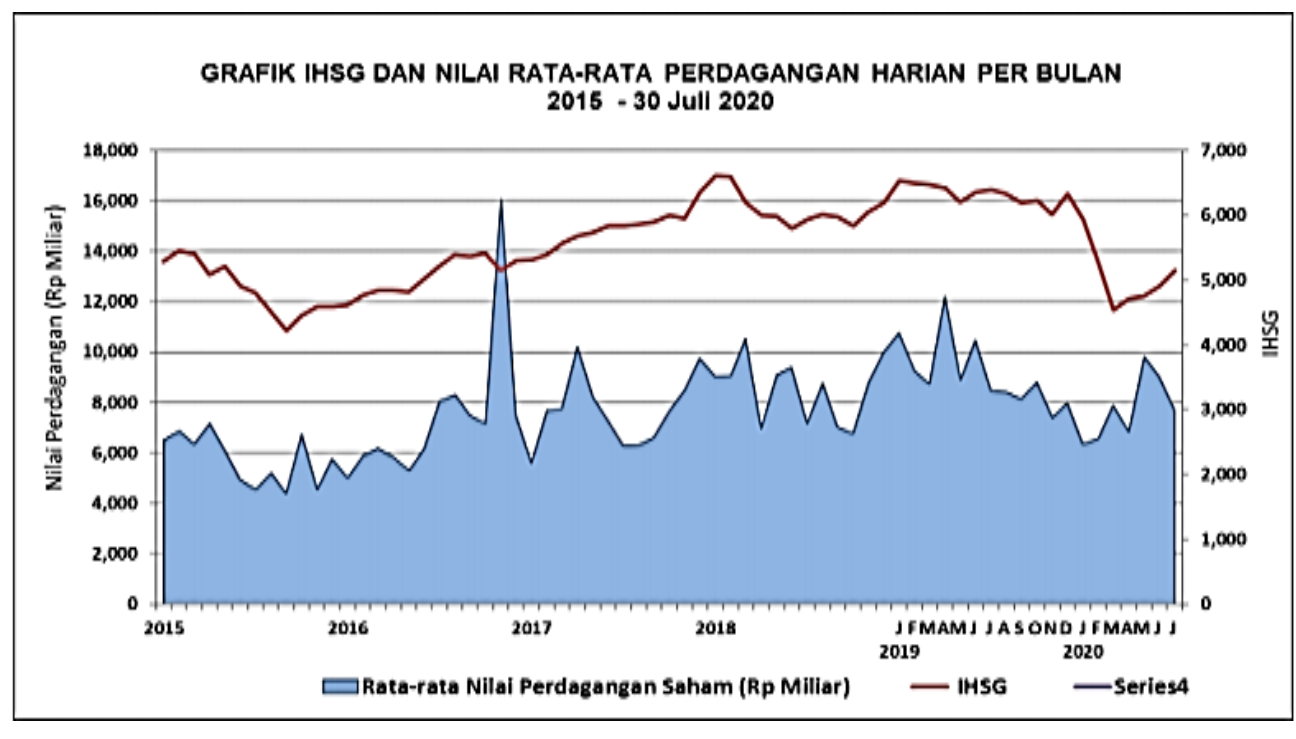

Grafik 1

Sumber: Otoritas Jasa Keuangan

Mengenai investasi syariah di dunia juga menunjukkan perkembangan pada beberapa tahun terakhir. Berdasarkan data dari Islamic Financial Services Board (IFSB) sektor pasar modal pada tahun 2018 berkembang dari tahun sebelumnya sebesar $27 \%$ dengan total aset senilai 591,9 Miliar Dolar Amerika. ${ }^{5}$ Hal ini menunjukkan bahwa potensi pengembangan pasar modal syariah secara global juga diperkirakan akan naik pada tahun-tahun berikutnya, khususnya di pusat keuangan syariah seperti di London dan Malaysia.

${ }^{3}$ John C Bluedorn et al., "Capital Flows are Fickle: Anytime, Anywhere," IMF Working Papers 13(183), 2013, pp 1, https://doi.org/10.5089/9781484389041.001.

${ }^{4}$ Otoritas Jasa Keuangan, "Statistik Mingguan, Juli Minggu Ke-5" (Jakarta, 2020), https://www.ojk.go.id/id/kanal/pasar-modal/data-dan-statistik/statistik-pasar-modal/Documents/5. Statistik Juli Mgg ke-5 2020.pdf.

5 Islamic Financial Services Board, "Islamic Financial Services Industry Stability Report 2019" (Kuala Lumpur, 2019), https://www.ifsb.org/download.php?id=5231\&lang=English\&pg=/index.php. 
Statistik perkembangan investor dan produk pasar modal syariah juga berbanding lurus dengan dikeluarkannya peraturan-peraturan mengenai pasar modal syariah. Berdasarkan penelitian dari Thomson Reuters, nilai aset keuangan syariah secara kuantitatif di Indonesia pada tahun 2017 adalah senilai 82 Miliar Dolar Amerika, menempati urutan ke delapan yang terbesar di dunia. ${ }^{6}$ Kemudian laporan dari OJK bahwa aset pasar modal syariah meningkat setiap tahun dari tahun 2014 sampai dengan 2018. Total aset pasar modal syariah pada tahun 2018 adalah 700,84 triliun rupiah dengan rincian 645.05 triliun rupiah berasal dari sukuk negara, 21,30 triliun rupiah berasal dari sukuk korporasi, dan 34,49 triliun rupiah berasal dari reksa dana syariah. Kemudian jumlah investor saham syariah, sukuk korporasi, dan reksa dan syariah meningkat menjadi 401.516 investor atau tumbuh sebesar 38,16\% pada tahun 2018 dibandingkan dengan tahun $2017 .^{7}$

Meningkatnya nilai aset pasar modal syariah dan investor pasar modal syariah, tentu berpotensi juga meningkatkan adanya sengketa antara para pihak dalam kegiatan investasi pasar modal syariah. Kemudahan berinvestasi di bidang pasar modal syariah menggunakan teknologi internet membuat naiknya jumlah investor yang berinvestasi di bidang ini, namun teknologi juga memiliki potensi sengketa antara pihak menjadi tinggi karena para pihak tidak dapat bertemu dan memastikan produk atau jasa secara langsung. Peluang tindak kejahatan yang dilakukan secara berkelompok maupun individu menggunakan teknologi juga dapat dikatakan menjadi tinggi. Adapun kewenangan menyelesaikan sengketa di bidang pasar modal syariah adalah Pengadilan Agama. Kompetensi absolut ini berdasarkan Undang-Undang Nomor 3 Tahun 2006 jo. Undang-Undang Nomor 50 Tahun 2009 tentang Perubahan Kedua atas Undang-Undang Nomor 7 Tahun 1989 Tentang Peradilan Agama yang menyatakan bahwa sengketa ekonomi syariah termasuk kewenangan Pengadilan Agama. ${ }^{8}$

6 Thomson Reuters, "Islamic Finance Development Report 2018," Thomson Reuters, 2018, https://ceif.iba.edu.pk/pdf/Reuters-Islamic-finance-development-report2018.pdf.

7 Otoritas Jasa Keuangan, "Laporan Perkembangan Keuangan Syariah Indonesia (LPKSI) 2018" (Jakarta, 2018), https://www.ojk.go.id/id/kanal/syariah/data-dan-statistik/laporan-perkembangankeuangan-syariah-indonesia/Documents/Laporan Perkembangan Keuangan Syariah Indonesia \%28LPKSI\%29 2018.pdf.

8 Kelik Pramudya, "Strategi Pengembangan Ekonomi Syariah Melalui Penguatan Fungsi Pengadilan Agama dalam Penyelesaian Sengketa," Jurnal Rechts Vinding: Media Pembinaan Hukum Nasional 7(1), 2018, hal 35, https://doi.org/10.33331/rechtsvinding.v7i1.216. 
Sayangnya Pengadilan Agama sebagai jalan terakhir penyelesaian sengketa ekonomi syariah khususnya sengketa pasar modal syariah masih memiliki beberapa kekurangan. Yakni penyelesaian kasus yang cukup lama, antrean pengadilan yang menyita waktu dan tenaga, prosedur dan syarat administrasi yang rumit. Kemudian tidak semua hakim Pengadilan Agama memiliki kemampuan yang memadai mengenai pasar modal syariah. ${ }^{9}$ Belum lagi dengan beban perkara menumpuk yang menjadikan beban pikiran hakim. Hal itu semua menjadikan Pengadilan Agama bukanlah solusi yang terbaik bagi penyelesaian sengketa bisnis, dikarenakan pelaku bisnis membutuhkan efisiensi waktu dan biaya demi keuntungan dan berjalanya bisnis di pasar modal. Oleh karena itu penyelesaian sengketa melalui jalur non litigasi atau sering disebut alternatif penyelesaian sengketa (APS) menjadi pilihan terbaik dalam penyelesaian sengketa bisnis khususnya sengketa pasar modal Syariah. ${ }^{10}$

Pada saat masa pandemi COVID-19 ini kontak fisik antar manusia sangat dihindari. Kebijakan physical distancing menjadi kebijakan yang wajib dilakukan oleh banyak lembaga. ${ }^{11}$ Termasuk lembaga penyelesaian sengketa di luar pengadilan juga wajib melaksanakan kewajiban tersebut demi mencegah penularan virus COVID-19. ${ }^{12}$ Pelaksanaan protokol kesehatan menjadi kendala bagi pelaksanaan APS karena tidak dapat dilaksanakan secara tatap muka langsung. Oleh karena itu butuh alternatif penyelesaian sengketa (APS) di luar pengadilan yang dapat dilaksanakan tanpa melalui tatap muka langsung. Penyelesaian Sengketa Daring atau Online Dispute Resolution (ODR) menjadi jalan keluar bagi pelaksanaan APS di masa pandemi dan menjadi potensi pilihan pelaksanaan APS di masa datang.

Penelitian serupa pernah dilakukan oleh Sugiarto pada tahun 2019 yang meneliti ODR secara umum yang ditinjau dari hukum Islam. ${ }^{13}$ Penelitian tersebut mengulas ODR

\footnotetext{
${ }^{9}$ Asep Saepullah, "Kewenangan peradilan agama di dalam perkara ekonomi syariah," Mahkamah: Jurnal Kajian Hukum Islam 1(2), 2016), https://doi.org/10.24235/mahkamah.v1i2.1305.

${ }^{10}$ H Abdul Manan dan S SH, Hukum Ekonomi Syariah: Dalam Perspektif Kewenangan Peradilan Agama (Prenada Media, 2017).

11 Wahyu Iswantoro, "Persidangan Pidana Secara Online, Respon Cepat MA Hadapi Pandemi Covid-19," Selisik: Jurnal Hukum dan Bisnis 6(1), 2020, hal 56-63, https://doi.org/10.35814/selisik.v6i1.1705.

12 Hamnach Burhanuddin, H Ahmad Fathonih, dan Aden Rosadi, "Layanan perkara secara elektronik (e-court) saat pandemi Covid-19 hubungannya dengan asas kepastian hukum" (Bandung: UIN Sunan Gunung Djati, 2020), http://digilib.uinsgd.ac.id/id/eprint/30922.

13 Suprihantosa Sugiarto, "Online Dispute Resolution (ODR) Sebagai Alternatif Penyelesaian Sengketa Di Era Modernisasi," Qawãnün: Journal of Economic Syaria Law 3(1)1, 2019): 50-65, https://doi.org/10.30762/q.v3i1.1484.
} 
secara umum dalam perspektif hukum Islam namun belum mengulas secara khusus untuk sengketa investasi syari'ah. Penelitian lain yang serupa juga pernah dilakukan oleh Dheka Ermelia Putri pada tahun 2019 yang meneliti penerapan ODR untuk penyelesaian sengketa nama domain. ${ }^{14}$ Penelitian tersebut telah mengetahui keunggulan ODR untuk sengketa hukum umum, untuk kemudian penulis akan meneliti secar khusus dalam bidang hukum Islam. Kemudian bahan penelitian untuk perbandingan pernah diteliti oleh Minas Arakelian, Olga Ivanchenko, dan Oleg Todoshchak yang meneliti tentang pengaturan hukum dan prosedur ADR menggunakan teknologi informasi di Uni Eropa dan Amerika Serikat. ${ }^{15}$ Penelitian tersebut penulis jadikan sebagai bahan perbandingan dengan pengaturan hukum ODR di Indonesia. Penelitian serupa selanjutnya tentang standar operasional prosedur minimal dalam ODR guna menjamin keadilan pernah dilakukan oleh Jie Zheng pada tahun 2010. Penelitian tersebut bersifat filosofis dengan dasar nilai keadilan umum sehingga butuh untuk dikembangka dalam penelitian nilai keislaman. ${ }^{16}$

Penelitian ini akan berfokus pada ODR untuk penyelesaian sengketa investasi syariah di Indonesia. Tujuan dari penelitian ini adalah untuk menemukan konsep baru dalam penyelesaian sengketa secara dalam jaringan (daring), khususnya terkait dengan pasar modal syariah dan mengetahui dasar hukum pelaksanaan ODR di Indonesia yang meliputi legalitas dan pengaturannya. Kemudian penelitian ini juga bertujuan untuk mengetahui permasalahan dan keunggulan ODR dibandingkan dengan penyelesaian sengketa yang lain.

\section{B. PERMASALAHAN}

Untuk mencapai tujuan dari penelitian ini maka diperlukan pertanyaan penelitian sebagai panduan awal dalam langkah-langkah penelitian. Oleh karena itu berdasarkan uraian masalah dalam latar belakang, perlu dicari jawaban dari pertanyaan penelitian yang memuat permasalahan yakni tentang:

${ }^{14}$ Dheka Ermelia Putri, “Application of Online Dispute Resolution (ODR) in International and Indonesia Domain Names Disputes," Lampung Journal of International Law 1(1), 2020, hal 19, https://doi.org/10.25041/lajil.v1i1.2021.

15 Minas Arakelian, Olga Ivanchenko, dan Oleg Todoshchak, "Alternative dispute resolution procedures using information technologies: legal regulation in the European Union and the USA," Revista Amazonia Investiga 9(26), 2020, pp 60-67, https://doi.org/10.34069/AI/2020.26.02.6.

16 Jie Zheng, "ODR Procedural Standards," in Online Resolution of E-commerce Disputes (Cham: Springer International Publishing, 2020), 211-79, https://doi.org/10.1007/978-3-030-54120-0_5. 
1. Bagaimana pengaturan online dispute resolution dalam sengketa pasar modal syariah di Indonesia?

2. Bagaimana keunggulan dan permasalahan online dispute resolution dalam sengketa pasar modal syariah di Indonesia?

\section{METODE PENELITIAN}

Penelitian ini menggunakan metode yuridis normatif, yakni metode yang meneliti peraturan hukum yang berlaku sebagai norma dogmatik yang perlu dipatuhi. ${ }^{17}$ Peraturan hukum yang akan diteliti adalah peraturan hukum mengenai pasar modal, pasar modal syariah, arbitrase dan penyelesaian sengketa baik di Indonesia dan negara lain sebagai perbandingan. Adapun negara yang dijadikan perbandingan dalam penelitian ini adalah negara Malaysia dan Amerika Serikat. Aturan hukum tentang ODR tersebut akan dianalisa kelemahan dan kelebihannya.

Kemudian data yang digunakan dalam penelitian adalah jenis data sekunder. Data sekunder adalah data yang diperoleh tidak langsung dari sumber awal namun berasal dari kajian pustaka berupa jurnal ilmiah, laporan penelitian, buku ilmiah, dan publikasi ilmiah lainnya. ${ }^{18}$ Dalam penelitian ini menggunakan data yang berkaitan dengan ODR dan penyelesaian sengketa pasar modal syariah. Untuk melengkapi metode tersebut juga digunakan metode analisa kualitatif, yakni menggunakan analisa penarikan logika dari kalimat. ${ }^{19}$ Adapun pendekatan yang digunakan untuk menganalisis permasalahan dalam penelitian ini adalah pendekatan filosofis, pendekatan konseptual, pendekatan kasus, dan pendekatan perbandingan hukum.

Kemudian penelitian ini akan mencari tahu kelemahan dan kelebihan ODR dibanding APS yang lain. Selanjutnya, dicari mengenai permasalahan ODR di Indonesia yang terdiri dari permasalahan dogmatika hukum dan permasalahan praktik ODR dalam penyelesaian sengketa pasar modal syariah. Lalu dari permasalahan ODR yang telah ditemukan tersebut diberikan rekomendasi sebagai solusi dari permasalahan.

${ }^{17}$ Kornelius Benuf dan Muhamad Azhar, "Metodologi Penelitian Hukum sebagai Instrumen Mengurai Permasalahan Hukum Kontemporer," Gema Keadilan 7(1), 2020, hal 20-33. https://doi.org/https://doi.org/10.14710/gk.7.1.20-33.

${ }^{18}$ Derita Prapti Rahayu, MH. SH, "Metode Penelitian Hukum," Yogyakarta: Thafa Media, 2020.

${ }^{19}$ Sulistyowati Irianto, "Metode Penelitian Kualitatif Dalam Metodologi Penelitian Ilmu Hukum," Jurnal Hukum \& Pembangunan 32(2), 2017, hal 155, https://doi.org/10.21143/jhp.vol32.no2.1339. 
e-ISSN : 2621-4105

\section{PEMBAHASAN}

\section{Pengaturan Penyelesaian di luar pengadilan untuk Sengketa Pasar Modal Syariah di Indonesia}

Pasar modal dapat diartikan sebagai tempat untuk menjualbelikan efek dari pihak yang melakukan penawaran umum (emiten) kepada para investor. Berdasarkan pasal 1 angka 5 Undang-undang pasar modal, efek didefinisikan sebagai surat berharga yang dapat berbentuk surat pengakuan utang, surat berharga komersial, saham, obligasi, tanda bukti utang, Unit Penyertaan kontrak investasi kolektif, kontrak berjangka atas Efek, dan setiap derivatif dari Efek. Adapun kegiatan pasar modal di Indonesia dilakukan oleh PT. Bursa Efek Indonesia (BEI). Adapun mengenai pasar modal syariah adalah pasar modal yang dikelola dan memiliki standardisasi berdasarkan hukum Islam.

Sengketa pasar modal Syariah termasuk dalam sengketa perdata Islam yang dalam penyelesaian sengketa melalui jalur di luar pengadilan (non litigasi) tunduk pada undang-undang nomor 30 tahun 1999 tentang Arbitrase dan Alternatif Penyelesaian Sengketa (UU AAPS). UU AAPS yang mengatur penyelesaian sengketa di luar pengadilan membedakan alternatif penyelesaian sengketa dengan arbitrase, sedangkan dalam praktiknya arbitrase sering digolongkan dalam alternatif penyelesaian sengketa karena dilakukan di luar pengadilan. Pasal 1 angka $1 \mathrm{UU}$ AAPS memberikan definisi arbitrase sebagai cara penyelesaian suatu sengketa perdata di luar peradilan umum yang didasarkan pada perjanjian arbitrase yang dibuat secara tertulis oleh para pihak yang bersengketa. Arbitrase mempunyai ciri yang berbeda dengan APS yakni harus berdasarkan perjanjian arbitrase yang disepakati para pihak, proses arbitrase dilakukan oleh lembaga arbiter yang berwenang, keputusan diserahkan kepada pihak arbiter, dan eksekusi dapat dimintakan kepada pengadilan jika pihak yang kalah tidak melaksanakan dengan suka rela.

Sedangkan alternatif penyelesaian sengketa (APS) menurut pasal 1 angka 10 UU AAPS adalah lembaga penyelesaian sengketa penyelesaian sengketa atau beda pendapat melalui prosedur yang disepakati para pihak, yakni penyelesaian di luar pengadilan dengan cara konsultasi, negosiasi, mediasi, konsiliasi, atau penilaian ahli. 
APS mempunyai ciri khas penyelesaian yakni penentuan keputusan berdasarkan kesepakatan para pihak bukan dari pihak ketiga, para pihak bersifat aktif dalam penyelesaian perkara, pihak ketiga diperlukan hanya sebagai pertimbangan atau penengah dalam perkara. Adapun pengertian dari masing-masing APS yakni: ${ }^{20}$

\section{Konsultasi}

Konsultasi merupakan aktivitas konsultasi atau perundingan seperti klien dengan penasihat hukumnya, berbentuk menyewa konsultan untuk dimintai pendapatnya dalam upaya menyelesaikan suatu masalah. Konsultan hanya memberikan pendapat hukum yang nantinya dapat dijadikan rujukan para pihak untuk menyelesaikan sengketanya.

2. Negosiasi

Negosiasi adalah proses yang dilakukan oleh dua pihak dengan permintaan (kepentingan) yang saling bertentangan dengan membuat suatu persetujuan secara kompromi dan memberikan kelonggaran. Kesepakatan tertulis yang dihasilkan melalui negosiasi bersifat final dan mengikat para pihak dan wajib didaftarkan di pengadilan negeri dalam jangka waktu 30 hari terhitung sejak tanggal dicapainya kesepakatan sebagaimana diatur dalam Pasal 6 ayat (7) dan ayat (8) UU AAPS.

\section{Mediasi}

Mediasi merupakan proses penyelesaian sengketa secara pribadi, informal dimana seorang pihak yang netral yaitu mediator, membantu para pihak yang bersengketa untuk mencapai kesepakatan. Mediator hanya berfungsi mengontrol proses negosiasi, mediator tidak membuat keputusan, dan mediator hanya memfasilitasi.

4. Konsiliasi

Konsiliasi adalah upaya para pihak dalam suatu konflik, dengan bantuan seorang pihak ketiga netral (konsiliator), mengidentifikasikan masalah, menciptakan pilihan-pilihan, dan mempertimbangkan pilihan penyelesaian.

\section{Penilaian Ahli}

${ }^{20}$ Abdul Manan, Hukum Ekonomi Syariah Dalam Perspektif Kewenangan Peradilan Agama, Edisi Kedu (Jakarta: Kencana, 2014). 
Penilaian ahli merupakan proses yang menghasilkan suatu pendapat obyektif, independen dan tidak memihak atas fakta-fakta atau isu-isu yang dipersengketakan oleh seorang ahli yang ditunjuk oleh para pihak yang bersengketa.

Praktik penyelesaian perkara di luar pengadilan dalam kasus sengketa pasar modal syariah di Indonesia belum pernah dilaksanakan di Indonesia, namun kasus penyelesaian sengketa di luar pengadilan dalam kasus pasar modal konvensional pernah terjadi. Tercatat bahwa pada Badan Arbitrase Pasar Modal Indonesia (BAPMI) telah melakukan menyelesaikan 3 (tiga) perkara pada tahun 2014 dari perkara yang didaftarkan pada kurun waktu 2009-2010. ${ }^{21}$ Jadi dapat disimpulkan bahwa arbitrase adalah cara yang paling sering dipakai dalam penyelesaian sengketa pasar modal di Indonesia.

Pengaturan mengenai penyelesaian sengketa dalam perkara perdata ekonomi umum sudah cukup diatur secara baik dalam UU AAPS. Namun pengaturan mengenai sengketa dalam bidang investasi pasar modal belum diatur secara khusus apalagi mengenai pasar modal Syariah. Dalam praktiknya kewenangan melakukan arbitrase dalam bidang pasar modal Syariah di Indonesia dilaksanakan oleh Badan Arbitrase Nasional Indonesia (BANI), Badan Arbitrase Syariah Nasional (BASYARNAS), dan Badan Arbitrase Pasar Modal Indonesia (BAPMI). Guna memenuhi standar syariah dalam penyelesaian sengketa pasar modal syariah, maka masing-masing lembaga tersebut memiliki kebijakan untuk memilih arbiter/ ajudikator/ mediator yang memiliki kemampuan di bidang pasar modal atau pasar modal syariah. Namun sayangnya belum ada ketentuan tertulis dari masing-masing lembaga tentang standar syariah dalam penyelesaian sengketa pasar modal syariah di luar pengadilan, seperti standard operational procedure (SOP), guideline, atau ketentuan tertulis lain.

\section{Pengaturan Online Dispute Resolution sebagai penyelesaian di luar pengadilan} dalam sengketa Pasar Modal Syariah di Indonesia.

Perkembangan teknologi informasi yang sangat cepat memang sudah seyogyanya diakomodir dengan perkembangan hukum, demi tercapainya efisiensi

${ }^{21}$ Sudiyana Sudiyana, "Pemberdayaan Peran Lembaga Arbitrase dalam Penyelesaian Sengketa Bisnis di Indonesia," PADJADJARAN Jurnal Ilmu Hukum (Journal of Law) 4(1), 2017, hal 122-42, https://doi.org/10.22304/pjih.v4n1.a7. 
kerja, nilai kemanfaatan, dan kepastian hukum tanpa mengurangi nilai keadilan dalam perkembangan hukum dan teknologi. Dalam UU AAPS, undang-undang nomor 8 tahun 1995 tentang pasar modal, maupun undang-undang lain, belum ada yang mengatur secara khusus dan terperinci tentang penyelesaian sengketa di luar pengadilan menggunakan media dalam jaringan atau sering disebut ODR. Namun dalam UU AAPS dan UU Pasar Modal tidak ada larangan untuk melaksanakan ODR, sehingga terbuka peluang untuk melaksanakan ODR dalam outcourt dispute resolution.

Di dalam pasal 18 undang-undang nomor 11 tahun 2008 tentang Informasi dan Transaksi Elektronik (ITE) dijelaskan mengenai konsep kontrak elektronik yang mengikat para pihak di Indonesia dan juga upaya penyelesaian sengketa untuk kasus transaksi elektronik. Dalam pasal 18 ayat (4) UU ITE disebutkan bahwa:

"Para pihak memiliki kewenangan untuk menetapkan forum pengadilan, arbitrase, atau lembaga penyelesaian sengketa alternatif lainnya yang berwenang menangani sengketa yang mungkin timbul dari transaksi elektronik internasional yang dibuatnya"

Ketentuan dalam Pasal 18 ayat (4) ini menjelaskan tentang kebebasan para pihak untuk menentukan forum pengadilan, arbitrase, atau APS lain yang diinginkan untuk menangani sengketa yang akan timbul dari transaksi internasional yang dibuat. Pasal ini menegaskan penerapan asas kebebasan berkontrak dalam sebuah peraturan yang berpotensi menimbulkan sengketa. Di dalam pasal ini para pihak harus memahami penyelesaian sengketa apakah yang paling menguntungkan para pihak. Mulai dari memilih cara penyelesaian, tempat penyelesaian, dan pihak yang menyelesaikan. Bisa jadi dalam praktik penyusunan kontra, para pihak memilih ODR sebagai cara penyelesaian sengketa tahap awal yang harus ditempuh. Karena sengketa pasar modal dapat digolongkan sebagai transaksi elektronik jika memenuhi kriteria dalam pasal 2 angka 1 UU ITE yakni perbuatan hukum yang dilakukan dengan menggunakan Komputer, jaringan Komputer, dan/atau media elektronik lainnya.

Kemudian pasal 18 ayat (5) disebutkan bahwa: 
"Jika para pihak tidak melakukan pilihan forum sebagaimana dimaksud dalam ayat (4), penetapan kewenangan pengadilan, arbitrase, atau lembaga penyelesaian sengketa alternatif lainnya yang berwenang menangani sengketa yang mungkin timbul dari transaksi tersebut, didasarkan pada asas internasional."

Pasal ini menjelaskan jika ada kekosongan hukum karena para pihak tidak menetapkan pengadilan, arbitrase, atau lembaga APS yang berwenang menangani sengketa, maka digunakan asas hukum internasional. Dari pasal ini dapat disimpulkan bahwa para pihak tentu lebih memilih cara penyelesaian sengketa yang paling menguntungkan para pihak berdasarkan hukum internasional. Jadi pasal ini memungkinkan penggunaan ODR berdasarkan hukum internasional. Pertanyaan lebih lanjutnya apakah pasal ini juga berlaku pada transaksi nasional. Menurut penulis karena tidak ada pasal yang mengatur transaksi elektronik nasional? Apakah menggunakan asas hukum perdata nasional? Hal ini perlu diteliti lebih lanjut.

UU ITE mengatur perlindungan bagi penyedia jasa ODR yakni dalam pasal 33 mengenai perbuatan yang dilarang. Dijelaskan dalam pasal tersebut bahwa setiap orang yang dengan sengaja dan tanpa hak atau melawan hukum melakukan perbuatan yang mengganggu sistim elektronik maka dapat dipidana berdasarkan pasal 49 UU ITE dengan penjara maksimal 10 (sepuluh) tahun dan/ atau denda maksimal Rp, 10.000.000.000,- (Sepuluh Miliar Rupiah). Penyedia jasa ODR termasuk dalam sistim elektronik yang jika diganggu dapat dikenakan pidana. Oleh karena itu dapat disimpulkan telah ada perlindungan penyedia jasa ODR di Indonesia atau sanksi pidana bagi penganggu pelaksanaan ODR di Indonesia.

UU ITE juga melindungi konsumen atau pengguna ODR sebagai sistim elektronik. Di dalam pasal 35 ayat (1) UU ITE dijelaskan bahwa:

"setiap orang dengan sengaja dan tanpa hak atau melawan hukum melakukan manipulasi, penciptaan, perubahan, penghilangan, perusakan, informasi elektronik dan/atau dokumen elektronik dengan tujuan agar 
informasi dan/atau dokumen elektronik tersebut dianggap seolah-olah data yang otentik."

Pasal ini melindungi pengguna ODR dengan memberikan melindungi pengguna jasa ODR dengan memberikan ancaman bagi setiap orang yang melakukan penipuan, penghilangan, perusakan, bahkan penciptaan informasi/ dokumen elektronik. Pidana yang diancamkan bagi setiap orang yang menyabotase data dalam ODR ini adalah ancaman penjara maksimal 12 (dua belas) tahun dan/ atau denda Rp. 12.000.000.000,- (Dua belas miliar rupiah).Tentunya dalam ODR kerahasiaan data menjadi sebuah hal yang sangat penting dan harus sesuai aslinya, tidak boleh hilang atau diubah.

UU ITE juga melindungi para konsumen dan penyedia jasa ODR melalui pasal 38 ayat (1) UU ITE yakni penegasan bahwa setiap orang dapat mengajukan gugatan terhadap pihak yang menyelenggarakan atau menggunakan ODR tetapi yang telah menimbulkan kerugian sesuai dengan peraturan perundang-undangan. Kemudian dijelaskan tentang partisipasi masyarakat dalam mendukung ODR sebagai bagian dari teknologi informasi. Dalam Pasal 41 ayat (1) UU ITE dijelaskan bahwa masyarakat dalam berpartisipasi aktif dalam penyelenggaraan sistim elektronik dan transaksi elektronik. Kemudian dalam Pasal 41 ayat (2) dijelaskan bahwa partisipasi tersebut dapat dilakukan melalui lembaga dan dijelaskan dalam Pasal 41 ayat (3) bahwa lembaga tersebut dapat memiliki fungsi konsultasi dan mediasi. Pasal ini menjadi pemicu diperbolehkannya masyarakat menyediakan teknologi dalam pelaksanaan konsultasi dan mediasi termasuk ODR sebagai penyelesaian sengketa pasar modal.

Undang-undang nomor 7 tahun 2014 tentang perdagangan (UU Perdagangan) juga menegaskan tentang penyelesaian sengketa di luar pengadilan yakni disebutkan dalam pasal 65 ayat (5) UU perdagangan bahwa:

"Dalam hal terjadi sengketa terkait transaksi dagang melalui sistem elektronik, orang atau badan usaha yang mengalami sengketa dapat menyelesaikan sengketa tersebut melalui pengadilan atau melalui mekanisme penyelesaian sengketa lainnya”. 
Pasal ini juga menegaskan bahwa bolehnya menggunakan penyelesaian sengketa lain di luar pengadilan. Penyelesaian sengketa lain tersebut salah satunya dapat berupa ODR.

Peraturan yang secara tegas menyebutkan kata online dispute resolution dapat ditemukan dalam Peraturan Pemerintah nomor 80 tahun 2019 tentang Perdagangan Melalui Sistem Elektronik (PP no. 80 tahun 2019). Disebutkan dalam pasal 72 ayat (2) PP no. 80 tahun 2019 yakni:

"Penyelesaian sengketa PMSE sebagaimana dimaksud ayat (1) dapat diselenggarakan secara elektronik (online dispute resolution) sesuai dengan ketentuan peraturan perundang-undangan”.

Kemudian dijelaskan dalam penjelasan pasal tersebut yakni:

"Pada dasarnya penyelesaian sengketa secara elektronik (online dispute resolution) kembali kepada kesepakatan para pihak. Hal tersebut dapat berbentuk mediasi secara elektronik yang diselenggarakan oleh profesional penunjang seperti advokat atau mediator, melalui lembaga arbitrase online yang telah terakreditasi, atau melalui lembaga pemerintahan yang berwenang untuk itu."

Pasal dan penjelasan tersebut menegaskan bahwa ODR sebagai alternatif penyelesaian sengketa sudah diakui dalam sengketa perdagangan elektronik. Termasuk pasar modal juga termasuk perdagangan elektronik jika pembeliannya melalui teknologi informasi. Sayangnya ketentuan perundang-undangan yang mengatur khusus mengenai ODR belum di Indonesia. Kemudian mengenai pasar modal maka perlu dibuat standar operasional prosedur ODR dari lembaga penyelesaian sengketa pasar modal.

\section{Kajian Perbandingan ODR di negara lain}

Di negara Malaysia belum ada aturan hukum khusus yang mengatur tentang ODR, namun dalam UU Jasa Keuangan Islam Malaysia tahun 2013 yang mengatur tentang industri jasa keuangan syariah juga di dalamnya mengatur tentang penyelesaian sengketa keuangan Islam di luar pengadilan telah memiliki dasar penyelesaian sengketa di luar pengadilan sebagai konsep ODR dan tidak ada larangan 
melaksanakan ODR. Konsep tersebut yakni tercantum dalam disaputi pasal 135 ayat (2) huruf e dimana Bank dapat membuat standar dalam keluhan pelanggan dan mekanisme penyelesaian sengketa. Hal ini mengisyaratkan bahwa bank dapat mempunyai spesifikasi standar penyelesaian sengketa sendiri, dengan tanpa mengesampingkan standar umum. ${ }^{22}$

Kemudian dalam Financial Ombudsman Scheme (FOS) Malaysia yang mempunyai fungsi hampir sama dengan Otoritas Jasa Keuangan (OJK) Indonesia telah menerbitkan skema keuangan Ombudsman atau Financial Ombudsman Scheme (FOS) Regulation tahun 2015 yang mengatur secara teknis dan detail penyelesaian sengketa keuangan Islam di Malaysia. Umar A. Oseni dan Sodiq Omoola berpendapat bahwa pengaturan ODR di Malaysia sangat tepat jika diatur secara teknis dalam FOS. ${ }^{23}$ Dalam pasal 18 ayat (1) FOS Regulation tahun 2015 disebutkan bahwa setiap segala sesuatu yang diberikan oleh FOS yang disetujui oleh para pihak yang bersengketa maka bersifat mengikat.

Ditemukan beberapa penelitian terdahulu mengenai awal praktik ODR di Malaysia. Dalam satu jurnal mengatakan bahwa mediasi dalam jaringan pertama di Malaysia pertama kali diluncurkan pada awal tahun 2017 melalui website www.mediate2resolveonline.com. Portal ini didirikan dan dikelola oleh dua mediator asal Malaysia yakni Tunku Alina Alias dan Gunavathi Subramaniam. Pelaksanaan ODR dalam portal ini tunduk pada undang-undang Mediasi Malaysia tahun 2012. Portal ini melayani mediasi hukum keluarga dan hukum ekonomi syariah. ${ }^{24}$ Sayangnya portal tersebut tidak bisa dibuka sampai saat penelitian ini dibuat.

Penelitian lain menyebutkan bahwa ada dua layanan ODR berbayar di Malaysia. Pertama bernama ODR Malaysia yang memproklamirkan dirinya sebagai situs ODR pertama di Malaysia. Situs ini menawarkan pelayanan asistensi negosiasi,

${ }^{22}$ Al Chukwuma Okoli, “ODR: An Islamic Jurisprudence Perspective,” Conflict Studies Quarterly 26, 2019, pp 53-67, https://doi.org/10.24193/csq.26.4.

${ }^{23}$ Umar A. Oseni dan Sodiq O. Omoola, "Prospects of an online dispute resolution framework for Islamic Banks in Malaysia," Journal of Financial Regulation and Compliance 25(1), 2017, pp39-55, https://doi.org/10.1108/JFRC-07-2016-0055.

${ }^{24}$ Nur Farahiyah Mohd Nasir, Zinatul Ashiqin Zainol, dan Muhamad Helmi Md Said, "Prospect and challenges of using online mediation in resolving domestic violence," International Journal of Psychosocial Rehabilitation 24(1), 2020, pp 621-32, https://doi.org/10.37200/IJPR/V24I1/PR200168. 
negosiasi otomatis, mediasi, dan penyelesaian konflik. ${ }^{25}$ Namun Ketika mengunjungi domain http://www.odrmalaysia.com/service.php tidak menuju situs ODR namun menuju ke situs layanan penyedia jasa teknologi dari Amerika Serikat https://www.tylertech.com/solutions-products/modria. Layanan kedua adalah Kuala Lumpur Regional Center for Arbitration (KLRCA). ${ }^{26}$ Situs ini menyediakan layanan ajudikasi, ajudikasi jalur cepat, konsilisasi/ mediasi, penyelesaian sengketa nama domain, dan penyelesaian sengketa nama sensitif. KLRCA sekarang berubah nama menjadi Asian International Arbitration Center (AIAC). Dalam pelaksanaan arbitrasi AIAC menyediakan layanan online berupa panduan pelaksanaan sengketa nama domain secara online, pengisian keluhan online, pengisian respons online, informasi status kasus secara online, dan putusan panel AIAC secara online. ${ }^{27}$ Namun untuk layanan ODR tidak disediakan platform khusus dan untuk layanan khusus pasar modal syariah belum tersedia standardisasi tertulis. ${ }^{28}$

Berbeda dengan pengaturan ODR di Amerika Serikat yang sudah cukup lengkap. Pengaturan mengenai ADR secara umum diatur dalam Undang-Undang Alternatif Penyelesaian Sengketa tahun 1998. UU tersebut mengatur standardisasi APS secara offline. ${ }^{29}$ UU tersebut mempersilahkan para pihak di pengadilan untuk melakukan perdamaian terlebih dahulu baik difasilitasi oleh pengadilan atau pihak lain. Adapun ketentuan mengenai ODR diatur dalam UNICITRAL Model Law dan International Corporation for Assigned Names and Numbers (ICANN) Rules for uniform domain name dispute resolution policy. Dalam perlindungan konsumen pengguna dan penyedia jasa ODR, Amerika Serikat memiliki Electronic Signatures in Global and National Commerce Act (E-Sign Act) atau undang-undang tanda

${ }^{25}$ Raini Hassan et al., "Setting-Up a Sulh-Based, Community Mediation-Type of Online Dispute Resolution (ODR) in Malaysia," SSRN Electronic Journal, February 2018 (2013), https://doi.org/10.2139/ssrn.2334648.

26 Ibid.

27 AIAC, "Guide to Domain Name Dispute Resolution" (Kuala Lumpur: AIAC, 2014), https://www.aiac.world/wp-content/arbitration/Domain-Name-Book_2018.pdf.

${ }^{28}$ Damian Clifford dan Yung Shin Van Der Sype, "Online dispute resolution: Settling data protection disputes in a digital world of customers," Computer Law and Security Review, 2016, https://doi.org/10.1016/j.clsr.2015.12.014.

. ${ }^{29}$ Danielle Linneman, "Online dispute resolution for divorce cases in Missouri: a remedy for the justice gap," in J. Disp. Resol. (HeinOnline, 2018), 281, https://scholarship.law.missouri.edu/jdr/vol2018/iss1/17/. 
tangan elektronik dalam perdagangan nasional dan global guna melindungi kerahasiaan data dan keaslian dokumen. ${ }^{30}$

Dalam Praktiknya pelaksanaan ODR di Amerika Serikat dapat dilakukan oleh pengadilan atau pihak swasta. Setiap negara bagian memiliki platform dan standar prosedur tersendiri yang berfungsi melengkapi standar prosedur ODR federal. Penyedia platform ODR juga sangat banyak di Amerika Serikat. Beberapa penyedia ODR diantaranya yakni: American Arbitration Association (AAA), An Olive Branch, Anywhere Arbitration, Community Legal Aid Social ODR, Cyber Settle, Equitable Mediation, Fair Claims, Holistic Solutions, Instant Mediations, International Corporation for Assigned Names and Numbers (ICANN), Kleros, Modria, Medron Spaces, Mediation Suites, dan lain sebagainya. Namun belum ada yang khusus dalam penyelesaian sengketa pasar modal syariah. ${ }^{31}$

\section{Keunggulan dan Tantangan Praktik ODR dalam sengketa Investasi Pasar Modal Syariah di Indonesia}

ODR mempunyai mekanisme yang berbeda dengan penyelesaian sengketa secara langsung. ODR mempunyai ciri khas yakni para pihak tidak bertemu secara langsung dalam satu tempat, tetapi terhubung melalui media video call yang tersambung melalui jaringan internet. Para pihak harus memiliki perangkat dan jaringan internet yang cukup untuk saling terhubung dalam forum penyelesaian sengketa. Oleh karena itu banyak penyedia jasa ODR harus mempunyai keahlian penyelesaian sengketa dan penguasaan teknologi. Perekaman dalam ODR juga merupakan hal penting bagi para pihak atau pihak ketiga untuk menentukan putusan, karena perekaman dalam ODR menjadi pertimbangan dalam mengambil putusan. ${ }^{32}$

Tata cara pelaksanaan ODR juga berbeda dengan tata cara pelaksanaan penyelesaian sengketa secara offline. Banyak penyedia jasa ODR memiliki halaman website khusus untuk pendaftaran kasus. Para pihak yang bersengketa dapat mendaftarkan kasusnya dengan cara mengisi formulir pengajuan ODR secara online.

${ }^{30}$ Arthur Pearlstein, Bryan Hanson, dan Noam Ebner, "ODR in North America," in Online Dispute Resolution: Theory and Practice A Treatise on Technology and Dispute Resolution (Hague: Eleven International Publishing, 2012), 443-64.

31 Norhaziyah Binti Mohammad Nor, "The Viability of Online Dispute Resolution Implementation" (Universiti Teknologi Malaysia, 2011).

${ }^{32}$ Doug Leigh dan Frank Fowlie, "Online Dispute Resolution (ODR) within Developing Nations: A Qualitative Evaluation of Transfer and Impact," Laws 3(1), 2014, pp 106-16.

https://doi.org/10.3390/laws3010106. 
Pengisian identitas dan detail kasus juga secara online, sehingga digitalisasi barang bukti adalah wajib. Misal foto, video, scan dokumen, rekaman, dan barang bukti lain. Kemudian setelah kasus dipelajari dan diterima oleh pihak ketiga sebagai penengah maka ditentukan waktu pelaksanaan ODR dan kesiapan para pihak. Setelah itu pelaksanaan ODR dilaksanakan dengan memastikan bahwa hanya para pihak yang diperkenankan ikut saja yang boleh ada dalam forum ODR online, hal ini demi kerahasiaan data para pihak. Kemudian dilaksanakan proses perdamaian para pihak dengan tujuan menentukan tujuan yang terbaik bagi para pihak (win-win solution). ${ }^{33}$

ODR memliki beberapa keunggulan dibandingkan ADR. ${ }^{34}$ ODR dapat menjangkau pihak yang membutuhkan secara lebih luas. Untuk perkara yang memiliki nilai ekonomi rendah atau ketika para pihak tinggal di wilayah yang berjauhan atau yurisdiksi yang berbeda, maka ODR adalah jalan terbaik secara efsiensi waktu dan biaya. ODR juga dapat diintegrasikan dengan ADR dalam hal-hal yang tidak bisa dilakukan secara online maka pertemuan tatap muka dapat tetap dilakukan. ODR juga memiliki format untuk merekam semua jalanya proses penyelesaian sengketa yang dapat digunakan untuk penelitian lebih dalam dan pembuktian.

Menurut Jennifer Pinsof ODR memiliki biaya yang sangat lebih murah daripada ADR. ${ }^{35}$ ADR sendiri sudah menekan biaya, apalagi diintegrasikan dengan ODR maka akan terjadi extreme savings cost. Hal ini terjadi karena biaya perjalanan dapat ditekan melalui pertemuan dalam jaringan. Walaupun fasillitas pertemuan online juga memerlukan biaya, namun termasuk lebih murah daripada biaya perjalanan. Keuntungan lain dari ODR adalah kenyamanan (convenient). ODR dapat dilaksanakan di tempat masing-masing sesuai dengan suasana yang diinginkan. Rumah atau kantor dapat menjadi pilihan. Waktu juga dapat menyesuaikan karena para pihak dapat menyepakati waktu yang diinginkan walaupun di luar jam kerja, jika sudah kesepakatan maka dapat tetap dilaksanakan.

${ }^{33}$ Lifan Yang dan Jingjing Xing, "Characteristics of Online Transaction Dispute Mediation Cases in Mobile Electronic Commerce," 1st ed. (Cham: Springer, 2020), 174-89, https://doi.org/10.1007/9783-030-50350-5_15.

34 Susan S. Raines, "Mediating in your pajamas: The benefits and challenges for ODR practitioners," Conflict Resolution Quarterly 23(3), 2006, pp 359-69, https://doi.org/10.1002/crq.143.

35 Jennifer Pinsof, "The Future of ODR: The Promise of Advancing Technology," Michigan Technology Law Review, 2019, https://mttlr.org/2015/10/the-future-of-odr-the-promise-of-advancingtechnology/. 
Tantangan pelaksanaan ODR di Indonesia yakni pengembangan kompetensi absolut dari penerapan ODR, pengembangan mekanisme ODR dengan mengadopsi ADR, termasuk pengaturan penerapan variasi fitur teknologi terhadap prosedur yang ada dan pengembangan kode etik pihak keempat (programmer computer) serta perlindungan data pribadi pengguna (user), koneksitas lembaga peradilan dan lembaga lain yang relevan terkait eksekusi, dan pengembangan eksekusi alternatif. ${ }^{36}$

ODR untuk sengketa pasar modal di Indonesia belum sepenuhnya dapat dilaksanakan secara maksimal. Aturan hukum yang belum jelas mengenai standar pelaksanaan ODR saja belum ada apalagi untuk pelaksanaan sengketa pasar modal syariah di Indonesia. ${ }^{37}$ Jangkauan internet yang belum merata ke seluruh wilayah Indonesia juga menjadi masalah apabila salah satu pihak berada di wilayah yang memiliki sinyal yang lemah dan komunikasi antar para pihak menjadi terganggu. ${ }^{38}$ Keamanan media juga perlu diperhatikan, mengingat para peretas (hacker) Indonesia termasuk dalam paling ahli dalam menyabotase keamanan data, oleh karena itu dibutuhkan media ODR yang benar-benar aman agar kerahasiaan para pihak terjaga dengan baik.

\section{E. PENUTUP}

Pengaturan ODR di Indonesia belum diatur secara umum dan secara khusus tentang ODR dalam sengketa pasar modal syariah. Namun UU AAPS tidak melarang adanya ODR, bahkan terdapat konsep penyelesaian sengketa yang dapat diakomodir menjadi ODR. Pengaturan hukum lain seperti di UU ITE dan UU Perdagangan juga mengisyaratkan adanya ODR melalui partisipasi masyarakat. ODR menjadi memiliki keunggulan dalam penyelesaian sengketa investasi syariah dengan efisiensi waktu, biaya, kenyamanan, dan lebih partisipatif. Namun penggunaan ODR perlu penguasaan teknologi dan kepercayaan lebih antar para pihak. Selanjutnya perlu aturan khusus bagi ODR penyelesaian sengketa investasi syariah melalui undang-undang. Hal ini perlu dilakukan demi harmonisasi hukum dengan perkembangan teknologi dan informasi.

${ }^{36}$ Jeremy Barnett dan Philip Treleaven, “Algorithmic Dispute Resolution-The Automation of Professional Dispute Resolution Using AI and Blockchain Technologies," The Computer Journal 61(3), 2018, pp 399-408, https://doi.org/10.1093/comjn1/bxx103.

${ }^{37}$ Meline Gerarita Sitompul, M Syaifuddin, dan Annalisa Yahanan, "Online Dispute Resolution (ODR): Prospek Penyelesaian Sengketa E-Commerce Di Indonesia,” Jurnal Renaissance 1(2), 2016, hal 75-93.

38 Susan Nauss Exon, "Ethics and Online Dispute Resolution: From Evolution to Revolution," Ohio St. J. on Disp. Resol. 32, 2017, pp 609. 


\section{DAFTAR PUSTAKA}

\section{Buku}

Abdul Manan. Hukum Ekonomi Syariah Dalam Perspektif Kewenangan Peradilan Agama. Edisi Kedua. Jakarta: Kencana, 2014.

AIAC. "Guide to Domain Name Dispute Resolution.” Kuala Lumpur: AIAC, 2014. https://www.aiac.world/wp-content/arbitration/Domain-Name-Book_2018.pdf.

Arthur Pearlstein, Bryan Hanson, dan Noam Ebner. "ODR in North America." In Online Dispute Resolution: Theory and Practice A Treatise on Technology and Dispute Resolution, 443-64. Hague: Eleven International Publishing, 2012.

Derita Prapti Rahayu MH SH, "Metode Penelitian Hukum." Yogyakarta: Thafa Media, 2020.

H Abdul Manan, dan S SH. Hukum Ekonomi Syariah: Dalam Perspektif Kewenangan Peradilan Agama. Prenada Media, 2017.

\section{Jurnal}

Al Chukwuma Okoli. "ODR: An Islamic Jurisprudence Perspective." Conflict Studies Quarterly, no. 26 (2019): 53-67. https://doi.org/10.24193/csq.26.4.

Asep Saepullah. "Kewenangan peradilan agama di dalam perkara ekonomi syariah." Mahkamah: Jurnal Kajian Hukum Islam 1, no. 2 (2016). https://doi.org/10.24235/mahkamah.v1i2.1305.

Damian Clifford, dan Yung Shin Van Der Sype. "Online dispute resolution: Settling data protection disputes in a digital world of customers." Computer Law and Security Review, 2016. https://doi.org/10.1016/j.clsr.2015.12.014.

Danielle Linneman. "Online dispute resolution for divorce cases in Missouri: a remedy for the justice gap." In J. Disp. Resol., 281. HeinOnline, 2018. https://scholarship.law.missouri.edu/jdr/vol2018/iss1/17/.

Dheka Ermelia Putri. "Application of Online Dispute Resolution (ODR) in International and Indonesia Domain Names Disputes." Lampung Journal of International Law 1, no. 1 (11 Agustus 2020): 19. https://doi.org/10.25041/lajil.v1i1.2021.

Doug Leigh, dan Frank Fowlie. "Online Dispute Resolution (ODR) within Developing Nations: A Qualitative Evaluation of Transfer and Impact." Laws 3, no. 1 (2014): 106-16. https://doi.org/10.3390/laws3010106.

Gerarita Sitompul, Meline, M Syaifuddin, dan Annalisa Yahanan. "Online Dispute Resolution (ODR): Prospek Penyelesaian Sengketa E-Commerce Di Indonesia." Jurnal Renaissance 1, no. 02 (2016): 75-93.

Herring Shava. dan Willie T Chinyamurindi. "The influence of economic motivation, desire for independence and self-efficacy on willingness to become an entrepreneur." The Southern African Journal of Entrepreneurship and Small Business Management 11, no. 1 (12 September 2019): 12. https://doi.org/10.4102/sajesbm.v11i1.234.

Jeremy Barnett, dan Philip Treleaven. "Algorithmic Dispute Resolution-The Automation of Professional Dispute Resolution Using AI and Blockchain Technologies." The Computer Journal 61, no. 3 (1 Maret 2018): 399-408. https://doi.org/10.1093/comjnl/bxx103. 
e-ISSN : 2621-4105

Jie Zheng. "ODR Procedural Standards." In Online Resolution of E-commerce Disputes, 211-79. Cham: Springer International Publishing, 2020. https://doi.org/10.1007/9783-030-54120-0_5.

John C Bluedorn, Rupa Duttagupta, Jaime Guajardo, dan Petia Topalova. "Capital Flows are Fickle: Anytime, Anywhere." IMF Working Papers 13, no. 183 (2013): 1. https://doi.org/10.5089/9781484389041.001.

Kelik Pramudya. "Strategi Pengembangan Ekonomi Syariah Melalui Penguatan Fungsi Pengadilan Agama dalam Penyelesaian Sengketa." Jurnal Rechts Vinding: Media Pembinaan Hukum Nasional 7, no. 1 (30 April 2018): 35. https://doi.org/10.33331/rechtsvinding.v7i1.216.

Kornelius Benuf, dan Muhamad Azhar. "Metodologi Penelitian Hukum sebagai Instrumen Mengurai Permasalahan Hukum Kontemporer." Gema Keadilan 7, no. 1 (2020): 20 33. https://doi.org/https://doi.org/10.14710/gk.7.1.20-33.

Lifan Yang. dan Jingjing Xing. "Characteristics of Online Transaction Dispute Mediation Cases in Mobile Electronic Commerce," 1st ed., 174-89. Cham: Springer, 2020. https://doi.org/10.1007/978-3-030-50350-5_15.

Minas Arakelian, Olga Ivanchenko, dan Oleg Todoshchak. "Alternative dispute resolution procedures using information technologies: legal regulation in the European Union and the USA." Revista Amazonia Investiga 9, no. 26 (21 Februari 2020): 60-67. https://doi.org/10.34069/AI/2020.26.02.6.

Miriam Zuk. Ariel H. Bierbaum, Karen Chapple, Karolina Gorska, dan Anastasia Loukaitou-Sideris. "Gentrification, Displacement, and the Role of Public Investment." Journal of Planning Literature 33, no. 1 (2 Februari 2018): 31-44. https://doi.org/10.1177/0885412217716439.

Nur Farahiyah Mohd Nasir, Zinatul Ashiqin Zainol, dan Muhamad Helmi Md Said. "Prospect and challenges of using online mediation in resolving domestic violence." International Journal of Psychosocial Rehabilitation 24, no. 1 (2020): 621-32. https://doi.org/10.37200/IJPR/V24I1/PR200168.

Raini Hassan, Hanna Ambaras Khan, Imad Fakhri Al Shaikhli, dan Nora Abdul Hak. "Setting-Up a Sulh-Based, Community Mediation-Type of Online Dispute Resolution (ODR) in Malaysia." SSRN Electronic Journal, no. February 2018 (2013). https://doi.org/10.2139/ssrn.2334648.

Sudiyana. "Pemberdayaan Peran Lembaga Arbitrase dalam Penyelesaian Sengketa Bisnis di Indonesia." PADJADJARAN Jurnal Ilmu Hukum (Journal of Law) 4, no. 1 (2017): 122-42. https://doi.org/10.22304/pjih.v4n1.a7.

Sulistyowati Irianto. "Metode Penelitian Kualitatif Dalam Metodologi Penelitian Ilmu Hukum." Jurnal Hukum \& Pembangunan 32, no. 2 (19 Juni 2017): 155. https://doi.org/10.21143/jhp.vol32.no2.1339.

Suprihantosa Sugiarto. "Online Dispute Resolution (ODR) Sebagai Alternatif Penyelesaian Sengketa Di Era Modernisasi." Qawãnïn: Journal of Economic Syaria Law 3, no. 1 (1 Januari 2019): 50-65. https://doi.org/10.30762/q.v3i1.1484.

Susan Nauss Exon. "Ethics and Online Dispute Resolution: From Evolution to Revolution.” Ohio St. J. on Disp. Resol. 32 (2017): 609.

Susan S. Raines. "Mediating in your pajamas: The benefits and challenges for ODR practitioners." Conflict Resolution Quarterly 23, no. 3 (2006): 359-69. 
e-ISSN : 2621-4105

https://doi.org/10.1002/crq.143.

Umar A. Oseni, dan Sodiq O. Omoola. "Prospects of an online dispute resolution framework for Islamic Banks in Malaysia." Journal of Financial Regulation and Compliance 25, no. 1 (13 Februari 2017): 39-55. https://doi.org/10.1108/JFRC-072016-0055.

Wahyu Iswantoro. "Persidangan Pidana Secara Online, Respon Cepat MA Hadapi Pandemi Covid-19." Selisik: Jurnal Hukum dan Bisnis 6, no. 1 (2020): 56-63. https://doi.org/10.35814/selisik.v6i1.1705.

\section{Laporan}

Islamic Financial Services Board. "Islamic Financial Services Industry Stability Report 2019." Kuala

Lumpur, 2019. https://www.ifsb.org/download.php?id=5231\&lang=English\&pg=/index.php.

Otoritas Jasa Keuangan. "Laporan Perkembangan Keuangan Syariah Indonesia (LPKSI) 2018.” Jakarta, 2018. https://www.ojk.go.id/id/kanal/syariah/data-danstatistik/laporan-perkembangan-keuangan-syariah-indonesia/Documents/Laporan Perkembangan Keuangan Syariah Indonesia \%28LPKSI\%29 2018.pdf.

-. "Statistik Mingguan, Juli Minggu Ke-5." Jakarta, 2020. https://www.ojk.go.id/id/kanal/pasar-modal/data-dan-statistik/statistik-pasarmodal/Documents/5. Statistik Juli Mgg ke-5 2020.pdf.

Thomson Reuters. "Islamic Finance Development Report 2018." Thomson Reuters, 2018. https://ceif.iba.edu.pk/pdf/Reuters-Islamic-finance-development-report2018.pdf.

\section{Tesis}

Norhaziyah Binti Mohammad Nor. "The Viability of Online Dispute Resolution Implementation." Universiti Teknologi Malaysia, 2011.

\section{Working Paper}

Hamnach Burhanuddin, H Ahmad Fathonih, dan Aden Rosadi. "Layanan perkara secara elektronik (e-court) saat pandemi Covid-19 hubungannya dengan asas kepastian hukum." Bandung: UIN Sunan Gunung Djati, 2020. http://digilib.uinsgd.ac.id/id/eprint/30922. 
e-ISSN : 2621-4105

\section{Internet}

Jennifer Pinsof. "The Future of ODR: The Promise of Advancing Technology.” Michigan Technology Law Review, 2019. https://mttlr.org/2015/10/the-future-of-odr-thepromise-of-advancing-technology/. 